Dept. of Forensic Medicine and Toxicology

Fac. of Veterinary Medicine

Head of Dept. Prof. Dr. A.A. Shaaban.

\title{
IMMUNOTOXIC RESPONSE OF FEMALE BALB/C MICE TO DIAZIONE; CARBOFURAN AND CYPERMETHRINE INSECTICIDES
}

(With 2 Tables)

\section{ABDEL-NASSER}

(Received at $30 / 11 / 1994$ )

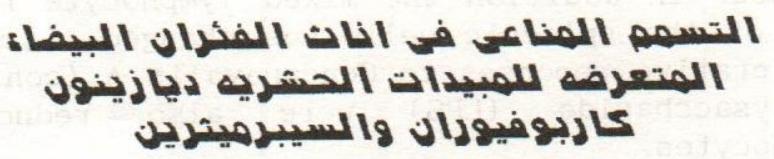

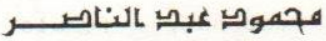

تم فى هذا البحث تقييم رد الفعل لدى الجههاز المناعى لـفئران ال BALB/C الاناث عند

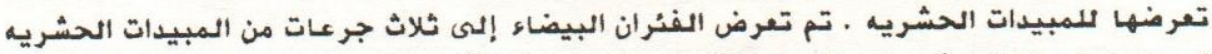

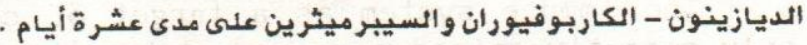

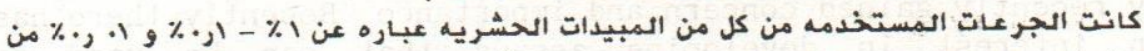

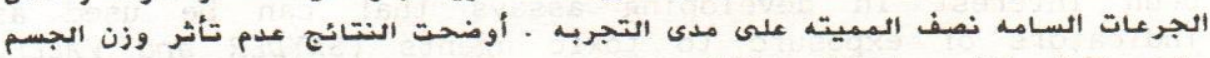

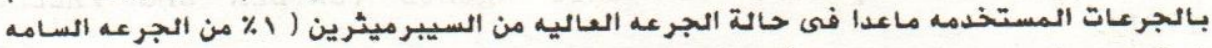

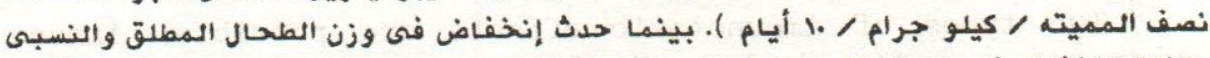

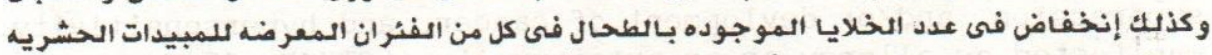

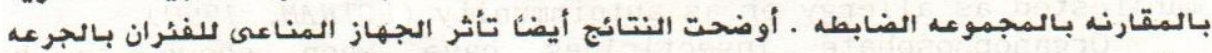

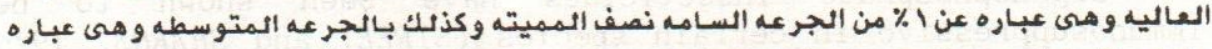

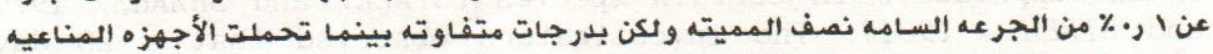

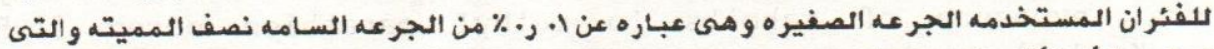

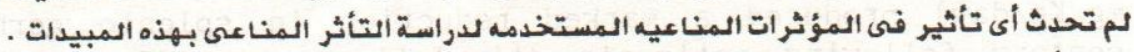

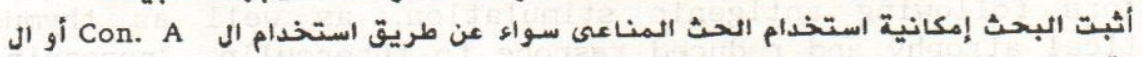

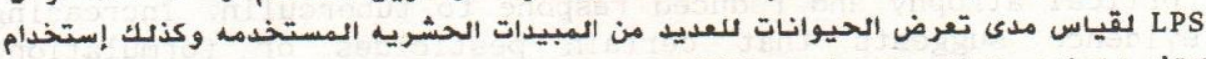

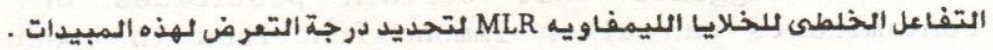




\section{SUMMARY}

The immunotoxic effect of diazinon, carbofuran and cypermethrin was evaluated in female BALB/C mice. Mice were dosed by gavage with $0.01,0.001$ and 0.0001 of the oral LDso of each technical insecticide. The lymphocyte proliferation assays were used to measure the functional activity of thymus-dependent (T-cells) and bursal equivalent (B-cells) lymphocytes by concanavalin A (con A) or lipopolysacharide (LPS). Mitogenesis or cell proliferation was measured by tritiated thymidine $\left({ }^{3} \mathrm{H}\right)$ incorporation. Results reveal, no changes in body weight except with the high dose of cypermethrin. Reduction in spleen cellularity and weight of intoxicated mice were recorded. In addition the mixed lymphocyte reaction (MLR) of the spleenic cells was changed. Lymphocyte proliferative reponses to Concanavalin A (con A) and Lipoplysaccharide (LPS) were also reduced in spleenocytes.

Keywords: Immunotoxic response, female balb/c mice, diazinon, carbofuran, cypermethrine, insecticides.

\section{INTRODUCTION}

The immune system as a target of chemical toxicants has only recently gained concern and importance. Recently there has been interest in developing assays that can be used as indicators of exposure to toxic agents (SNYDER and VALLE, 1991).

Two types of immunotoxic effects are possible; immunosuppression, and/or devlopment of cancer, and hypersensitivity, manifested as allergy or as autoimmunity (BOTHAM, 1990).

Organophosphate insecticides have been shown to be immunosuppressive in certain species (STREET and SHARMA, 1974 and STREET, 1981). The investigators observed that a 28 day oral exposure of rabbits to methyl parathion dosed (1.5 $\mathrm{mg} / \mathrm{Kg} /$ day) produced a marked reduction in splenic germinal centers following antigenic stimulation, as well as thymus cortical atrophy and reduced respone to tuberculin. Increasing evidence suggests that certain pesticides or formulations contaminants can alter immune functions in rodents, although studies in humans are limited and ambiguous (STREET, 1981, THOMAS et al., 1990 a).

OLSON et al., (1987) reported an unusual inverse doserelated suppression of antibody response in mice following Assiut Vet. Med. J. Vol. 32 No. 64, January 1995. 
exposure to aldicarb at concetration of $1 \mathrm{ppb}$ in drinking water for 34 days. In contrast, THOMAS et al., (1987, 1990 b), using similar exposure conditions that encompassed and exceeded earlier concentrations were unable to substantiate immune modulation or altered, susceptibility to challenge with infective agents in aldicarb-treated mice.

The newest major class of insecticides is the synthetic pyrethroids; a group of chemicals just entering the marketplace in 1980 , but by 1982, accounting for approximately 30 percent of the worldwide insecticide usage (VIJVERBERG and VANDEN $B E R C K E N$ 1982). Recent reports have appeared in the literature from the people's Republic of China, where synthetic pyrethrodis have been used on a large scale on cotton crops since 1982 (STUART-HARLE, 1988 and HE et al 1988 and 1989), there has been speculations about the relationship between these insecticides and clinical manifestations appeared on subjects engaged in packaging of them.

The measured parameters were restricted to factors such as serum immunoglobulins levels or T-lyphocyte numbers and gross observable toxicity. Recently there has been interest in developing assays that can be used as indicators of exposure to toxic agents. The aim of this work was to evaluate the use of spleenocytes proliferation assays as a tool for detection of pesticide exposure. In addition assessment of the immunotoxic effect of diazinon, carnofuran and cypermethrin on female BALB/C mice was also our goal.

\section{MATERIALS AND METHODS}

\section{Animals and Treatments:}

Female BALB/C mice, 6 weeks old and 20 to $23 \mathrm{~g}$ weight were classified into three groups, 10 each. For each of the selected pesticides $0.01 \%, 0.1 \%$ and $1 \%$ of the oral LD50 were given daily for 10 days dissolved in corn oil, one group kept as control and dosed with corn oil.

C57 BL/6 mice were the source of stimulator cells for the mixed lymphocyte reaction (MLR). All mice were purchased from Harlan Sprague Dawley, Inc., Indianapolis, USA. The animals were maintained on a 12/12-light and dark cycle and were provided with food and water ad libitum.

The insecticides were of technical qrades (98-99\% active ingredients) supplied from Chem Service Company, West Chester, PA, USA.

Immune Parameters:

At the end of the experiment, mice were allowed to rest for 3 days after which they were wighed and killed by cervical

Assiut Vet. Med. J. Vol. J. 32 No. 64, January 1995. 
dislocation and then the spleen was removed aseptically and weighed. Then placed in petri dish and mashed in RPMI-1640 medium with a sterile syringe barrel, and made into one cell suspension by passing through a $25 \mathrm{G}$ needle and adjusted to the needed concentration.

Mitogen-stimulated lymphoproliferative responses of spleen cell suspensions were measured by tritited thymidine ( $\mathrm{H}-\mathrm{TdR})$ incorporation (SMIALOWICZ, et al, 1985).

Spleen cells were suspended in suplemented RPMI-1640 medium, containing $25 \mathrm{mM}$ HEPES, $2 \mathrm{mM} \mathrm{L-glutamine,} 50 \mu \mathrm{g} / \mathrm{ml}$ gentamycin and $5 \%$ calf bovine serum.

The 72-h lymphoroliferative responses of spleen cells from individual control and treated mice were determined in triplicate at several concentrations of each mitogen for counting the radioactivity in radioactively-tagged samples and determination of total counts and counts per minutes $(\mathrm{cpm})$ of each sample, using Beckman LS-3801 Liquid Scintillation Counter.

Harvesting of cells usunig cell harvester supplied from Skatron Co., then the samples, in multi-purpose premixed liquid scintillation cocktails, were placed in special vials. The vials were placed into the sample changer of the Liquid Scintillation Counter to be measured.

The one way mixed lymphocyte reaction (MLR) was performed using responder (Pesticed-dosed BALB/C mice) splenic lymphocytes according to the nethod of BRADLY (1980).

Stimulator cells were treated with mitomycin C at $50 \mu \mathrm{g} / \mathrm{ml}$ for 40 minutes at $37^{\circ} \mathrm{C}$ and $5 \% \mathrm{Co} 2$, washed three times and resuspended at $4 \times 10^{6} \mathrm{cell} \mathrm{s} / \mathrm{ml}$ in supplemented RPMI-1640 medium containing $5 \times 10^{-5} \mathrm{M}$ 2-mercaptoethanol (2-ME). Responder cells were resuspended in the same medium at $2 \times 10^{6} \mathrm{cells} / \mathrm{ml}$. To triplicate wells of round-bottom microtiter plates containig $2 \times 10^{5}$ responder cells were added complete medium or $2 \times 10^{5}$ stimulator cells in a total volume of $200 \mu 1$. In addition, wells containig stimulator cells plus Con A set up as an internal control for the efficacy of the mitomcin-C treatment of stimulator cells. MLR cultures were incubated for $96 \mathrm{~h}$ at $37^{\circ} \mathrm{C}$ and $5 \% \mathrm{CO}_{2}$. Four hours prior to harvest, cultures were labeled with $1.00 \mu \mathrm{ci} /$ well ${ }^{3} \mathrm{H}-\mathrm{TdR}$ (specific activity $6.7 \mathrm{ci} / \mathrm{mM}$ ) in $10 \mu \mathrm{l} / \mathrm{we} 1 \mathrm{l}$. The results are expressed as the net counts/min., subtracting the counts/min. of responder only cultures from the counts/min. of responder plus stimulator cultures, according to SMIALOWICZ et al., (1992). 


\section{RESULTS}

The effect of different doses of diazinon, carbofuran and cypermethrin insecticides on spleen and body weight of BALB/C mice is summerized in table 1. Body weight was not affected by the sued doses except in case of $0.025 \mathrm{mg} / \mathrm{kg} /$ day cypermethrin. Spleen weght was reduced and this reduction was dose dependant. The relative spleen weight was also reduced in relation to body weight. The cellularity of the spleen was affected in comparison to the control group of mice. Table 2, shows the effect of the selected doses of the pesticides on the proliferative responses of spleenocytes taken from female BALB/C mice. The Iymphproliferative response to mitogenstimulation and to the MLR of spleenocytes from mice exposed to the dose $0.01 \%$ of LD50 of the three pesticides were unaltered. However, spleenocytes from mice dosed $0.1 \%$ and $1.0 \%$ of LD50 when cultured with Con A or LPS, had reduced proliferation responses compared with control but at different levels.

\section{DISCUSSION}

Pesticides constitute a very important group of chemicals released into the environment. The influence on any of pesticides on the immune system or immune response has been nearly totally ignored despite obvious health implications. Our study was performed to determine whether the selected pesticides alter the immune function of BALB/C mice. Exposure of mice to $1.0 \%$ of oral LD50 of pesticides $10.3 \mathrm{mg} / \mathrm{kg} /$ day diazinone; $0.008 \mathrm{mg} / \mathrm{kg} / \mathrm{day}$ carbofuran and $0.025 \mathrm{mg} / \mathrm{kg} / \mathrm{day}$ cypermethrin) resulted in a significant reduction in immune functions. The dose of pesticide along with the 10 days do not exceed $1.0,0.1$ and $0.01 \%$ of the oral LD50. A dose of $0.01 \%$ of LD50 along with 10 days found to be tolerated by female BALB/C mice. The moderate dose of $0.1 \%$ of LD50 gave a moderate immunotoxic effect in the treated mice.

Body weight was unaltered at any of the exposed mice or any dose level of the three pesticides except those exposed to $0.025 \mathrm{mg} / \mathrm{kg} /$ day of cypermethrin. Spleen weight was reduced with the exposure of pesticides, and spleenocyte number was also decreased in a dose related manner. Spleenocyte proliferative responses to Con A, LPS and MLR were significantly reduced and this reduction seems to be dose-dependant. Accordeing to LUSTER, et al., (1993), a good correlation exists between changes in the immune tests and host resistance in that there were no instances where host resistances was altered without affecting an immune test or tests.

Assiut Vet. Med. J. Vol. J. 32 No. 64, January 1995. 
Certain xenobiotics or their metabolites can damage immunocomptence by directy interacting with one or more of the cells of the immue system and adversely affecting its function. It has also been proposed that xenobiotics may indirectly affect immune function by affecting other organ systems that will in return affect immunocompetence (FUCHS and SANDERS, 1994). Organophosphate as well as carbamte pesticides have been reported to alter normal immune function (RODGERS, et al 1986 and $D E A N$ et al 1990). Cypermethrin as a member of the new generation of insecticides, pyrethroids, has been shown to reduce both humoral and cellular immune respone (DESI et $\underline{\text { al }}$ 1985 and TAMANG et al 1988).

The results of this study indicated that spleenocyte proliferation assays may be applicable as biomarkers of exposure for a wide variety of pesticides as diazinon, carbofuran and cypermethrin.

These assays are also applicable for the detection of immuntoxic effects of pesticides. Finally many further investigations are needed to obtain a more detailed picture of pesticide immunotoxicity.

\section{REFERENCES}

Botham, P.A. (1990): Are Pesticides immunotoxic? Adverse Drug React. Acute Poisoning Rev, 9(2): 91-101.

Bradly, L.M. (1980): Mitogen-induced responses. In: B.B. Mischell and S.M.Shiigi (Eds), Selected Methods in Cellular Immunology, W.H. Freeman and Comany, San Francisco, First eddition, PP. 162-172.

Dean, T.N.; Kakkanaiah, V.N.; Nagarkatti, M. and Nagarkatti, P.S. (1990): Immunosuppression by aldicarb of T-Cell responses to antigen-specific and polyclonal stimuli results from defective II-1 production by the macrophages. Toxicol. Appl. Pharmacol., 106: 408-417.

Desi, I.; Varga, L.; Dobronyi, I. and Szkenarik, G. (1985): Immunotoxic investigation of the effects of pesticide; permethrin. Arch. Toxicol. Suppl., 8: 305-309.

Fuchs, B.A. and Sanders, V.M. (1994): The role of brain-immune interactions in immunotoxicology. Crit. Rev. Toxicol., 24(2): 151-176.

He, F.; Sun, J. ; Han, K.; Wu, Y.; Wang, S. and Lin, L. (1988): Effect of pyrethroid insecticides on subject engaged in packaging pyrethroids. Bt. J. Indust. Med., 45: 548-551.

He, F., Wang, S.; Lin, L.; Chen, S.; Zhang, Z. and Sun, J. (1989): Clinical manifestations and diagnosis of acute pyrethroid poidoning. Arch. Toxicology, 63: 54-58.

Assiut Vet. Med. J. Vo1. 32 No. 64, January 1995. 
Luster, M.I.; Portier, C.; Pait, D.G.; Rosenthal, G.J. ; Germolec, D.R.; Corsini, E. 1 Vlaylock, B.L.; Poollock, P. ; Kouchi, $Y$ and Craig, W. (1993): Risk assessment in immunotoxicology, II-Relationship between immune and host resistance tests. Fundoam. Appl. Toxicol., 21(1): 71-82.

Olson, L.J.; Erickson, B.J.; Hinsdill, R.D. ; Wyman, J.A. ; Peter, W.P. ; Binning, L.K. ; Bidgood, R.C. and Nordheim, E.V. (1987): Aldicarb immunomodulation in mice: an inverse dose-response to parts per billion levels in drinking water. Arch. Environ. Contam. Toxicol., 16: 433-439.

Rodgers, K.E.; Imanura, T. and Devens, B.H. (1986): Organophosphorus pesticides immunotoxicity: Effects of 0,0, S-trimethyl phosphothioate on cellular and humoral immune response systems. Immunopharcol., 12: 193-1202.

Smialowicz, R.J.; Luebke, R.W.; Rogers, R.R.; Riddle, M.M. and Rowe, D.G. (1985): Evaluation of immune function in mice exposed to ordam. Toxicology, 37: 307-313.

Smialowicz, R.J.; Luebke, R.W. and Riddle, M.M. (1992): Assessment of the immunotoxic potential of the fungicide dinocap in mice. Toxicology, 75: 235-247.

Snder, C.A. and Valle, C.D. (1991): Lymphocyte proliferation assays as potential biomarkers for toxicant exposures. Journal of Toxicology and Environmental Health, 34: 127-139.

Street, I.C. (1981): Pesticides and the immune system. In: Sharma, R.P. (ed.) "Immunologic considerations in Toxicology" CRC Press, Inc., Boca Raton, Fla., First Eddition, pp. 46-66.

Street, J.C. and Sharma, R.P. (1974): Quantitative aspects of immunosupression by selected pesticides. Toxicol. Appl. Pharmacol., 29: 135-136.

Stuart-Harle, M. (1988): "Safe" pesticides found toxic. Biotechnology, 3: 16-18.

Tamang, R.K.; Jha, G.J.; Gupta, M.K.; Chauhan, H.V. and Tiwary, B.K. (1988): In vivo immunosuppression by sythetic pyrethroid (cypermethrin) pesticide in mice and goats. Vet Immunol. Immunopathol., 19: 299-305.

Thmas, p.T.; Ratajczak, H.V.; Eisenberge,W.C.; Furedi-Machacok, M; Ketels, K.V. and Barbera; R.W. (1987): Evaluation of host resisance and immunity in mice exposed to the carbamate pesticide aldicarb. Fund. Appl. Toxicol., 9: 82-89.

Thomas, P.T.; Busse, W.W.; Kerlvliet, N.I.; Luster, M.T.;Munson, A.E.; Murray, M. ; Robert, D.; Robinson, M. ; silkworth, $J$; Syoblad, $R$. and simialowicz, $R$. (1990 a): Immunologic effect of Pesticides, In Baker, S.R. and

Assiut Vet. Med. J. Vol. J. 32 No. 64, January 1995. 
Wilkinson, C.F. (eds.): The effect of pesticides on human health; Vol. 18, Prenceton Scientific Publisher, Inc., New York, PP. 305-313.

Thomas, P.T.; Ratajczak, H.V.; Demetral, D.; Hagen, K. and Baron, R. (1990 b): Aldicarb immunotoxicology: Functional analysis of cell mediated immunity and quantitation of lumphocyte subpopulations. Fund. Appl. Toxicol., 12: 90-95. Vijverberg, H.P.M. and Vanden Beerckman, J (1982): structure related effects of pyrethroids insecticides of the lateral line sense organ and on peripheral nerves of the clawed frog, Xenopus laerus. Pestic. Biochem. Physiol., 18:315324.

Table 1. The effect of pesticides on body and spleen weights and cellularity in female $\mathrm{B} \Lambda \mathrm{LB} / \mathrm{C}$ mice.

\begin{tabular}{|c|c|c|c|c|c|c|}
\hline \multirow{3}{*}{ Pesticides } & \multirow{3}{*}{$\begin{array}{c}\text { Dose } \\
(\mathrm{mg} / \mathrm{kg} / \text { day })\end{array}$} & \multicolumn{5}{|c|}{ Parameters } \\
\hline & & \multicolumn{2}{|c|}{ Body weight (g) } & \multirow{2}{*}{$\begin{array}{c}\text { spleen weight } \\
\text { (mg) }\end{array}$} & \multirow{2}{*}{\begin{tabular}{|c|} 
Relative \\
spleen \\
weight $(\%)$
\end{tabular}} & \multirow{2}{*}{$\begin{array}{l}\text { spleenocytes } \\
\qquad 10^{7} / \mathrm{ml}\end{array}$} \\
\hline & & A & B & & & \\
\hline \multirow{3}{*}{ Diazinon } & 0.3 & $21.60 \pm 1.75$ & $21.03 \pm 1.85$ & $98.75 \pm 5.33^{* *}$ & 0.470 & $3.55 \pm 0.21^{\star}$ \\
\hline & 0.03 & $22.40 \pm 2.20$ & $22.23 \pm 2.21$ & $106.25 \pm 7.33^{* *}$ & 0.478 & $3.78 \pm 0.25$ \\
\hline & 0.003 & $21.56 \pm 2.20$ & $21.37 \pm 1.99$ & $95.00 \pm 5.11^{*}$ & 0.445 & $3.25 \pm 0.31^{\circ}$ \\
\hline \multirow{3}{*}{ Carbofuran } & 0.008 & $21.00 \pm 1.55$ & $21.40 \pm 2.01$ & $97.50 \pm 6.15^{* *}$ & 0.456 & $2.75 \pm 0.33^{* *}$ \\
\hline & 0.0008 & $23.00 \pm 1.89$ & $22.49 \pm 2.21$ & $102.50 \pm 5.65^{*}$ & 0.456 & $3.03 \pm 0.28^{\approx \pi}$ \\
\hline & 0.00008 & $22.00 \pm 2.05$ & $22.17 \pm 1.57$ & $100.11 \pm 6.75^{*}$ & 0.487 & $3.37 \pm 0.24^{*}$ \\
\hline \multirow{3}{*}{ Cypermethrin } & 0.025 & $22.21 \pm 1.98$ & $18.77 \pm 1.57^{* \star}$ & $98.50 \pm 7.65^{* *}$ & 0.495 & $3.01 \pm 0.19^{* \pm}$ \\
\hline & 0.0025 & $22.11 \pm 1.87$ & $21.82 \pm 1.76$ & $98.75 \pm 6.88^{\text {*t }}$ & 0.456 & $3.62 \pm 0.15^{*}$ \\
\hline & 0.00025 & $22.22 \pm 2.08$ & $21.33 \pm 1.96$ & $97.98 \pm 5.33^{* \star \hbar}$ & 0.431 & $3.66 \pm 0.21$ \\
\hline Control & $\ldots$ & $22.45 \pm 1.65$ & $22.35 \pm 2.15$ & $118.75 \pm 5.88$ & 0.594 & $3.98 \pm 0.22$ \\
\hline
\end{tabular}

A: Weight befor dosing

B. Weight after the end of the experiment ( 13 day).

* Significant at $\mathrm{P}<0.05$.

** Significant at $\mathrm{P}<0.01$

Assiut Vet. Med. J. Vol. 32 No. 64, January 1995. 
Table 2. The effect of pesticides on the lymphproliferative response of spleenocytes from female BALB/C mice.

\begin{tabular}{|c|c|c|c|c|}
\hline \multirow{2}{*}{ Pesticides } & \multirow{2}{*}{ Dose } & \multicolumn{3}{|c|}{ Spleenocyte response (counts/min.) $\times 10^{4}$} \\
\hline & & ConA & & Mh \\
\hline \multirow{3}{*}{ Diazinon } & 0.3 & $24.54 \pm 3.13^{* *}$ & $18.65 \pm 2.15$ & $28.33 \pm 1.13^{\text {k* }}$ \\
\hline & 0.03 & $29.44 \pm 2.53^{\text {** }}$ & $19.88 \pm 1.38$ & $33.21 \pm 2.05^{\star \star}$ \\
\hline & 0.003 & $35.01 \pm 1.64^{\star}$ & $20.58 \pm 1.38$ & $40.36 \pm 2.51$ \\
\hline \multirow{3}{*}{ Carbofuran } & 0.008 & $29.90 \pm 3.56^{\star \star *}$ & $10.66 \pm 1.55^{\star * *}$ & $37.87 \pm 3.04^{\star \star *}$ \\
\hline & 0.0008 & $28.67 \pm 2.03^{* *}$ & $13.54 \pm 0.98^{* *}$ & $41.86 \pm 2.12$ \\
\hline & 0.00008 & $33.62 \pm 2.25^{\star}$ & $16.71 \pm 2.35^{*}$ & $41.77 \pm 3.25$ \\
\hline \multirow{3}{*}{ Cypermethrin } & 0.025 & $29.76 \pm 1.98^{\star \star *}$ & $15.53 \pm 1.75$ & $37.53 \pm 2.78^{\star \star}$ \\
\hline & 0.0025 & $29.82 \pm 2.33^{\star \star}$ & $17.31 \pm 1.73$ & $36.85 \pm 3.64^{*}$ \\
\hline & 0.00025 & $34.56 \pm 2.84$ & $17.53 \pm 1.11$ & $41.75 \pm 3.56$ \\
\hline Control & $\ldots$ & $36.83 \pm 315$ & $18.90 \pm 1.85$ & $42.66 \pm 3.41$ \\
\hline
\end{tabular}

Con A: Concanavalin A.

LPS : Lipopolysaccharide.

MLR: Mixed lymphocyte reaction.

* Significant at $\mathrm{P}<0.05$.

** Significant at $\mathrm{P}<0.01$. 